\title{
Author Correction: Chromatin accessibility landscapes of skin cells in systemic sclerosis nominate dendritic cells in disease pathogenesis
}

Qian Liu, Lisa C. Zaba, Ansuman T. Satpathy (1), Michelle Longmire, Wen Zhang, Kun Li (D, Jeffrey Granja, Chuang Guo (1), Jun Lin (1), Rui Li, Karen Tolentino, Gabriela Kania, Oliver Distler, David Fiorentino, Lorinda Chung, Kun Qu (D) \& Howard Y. Chang (D)

Correction to: Nature Communications https://doi.org/10.1038/s41467-020-19702-z, published online 17 November 2020.

The original version of this Article contained an error in the spelling of the author Lisa C. Zaba, which was incorrectly given as Lisa Zaba. This has now been corrected in both the PDF and HTML versions of the Article.

Published online: 14 December 2020

(c) (i) Open Access This article is licensed under a Creative Commons Attribution 4.0 International License, which permits use, sharing, adaptation, distribution and reproduction in any medium or format, as long as you give appropriate credit to the original author(s) and the source, provide a link to the Creative Commons license, and indicate if changes were made. The images or other third party material in this article are included in the article's Creative Commons license, unless indicated otherwise in a credit line to the material. If material is not included in the article's Creative Commons license and your intended use is not permitted by statutory regulation or exceeds the permitted use, you will need to obtain permission directly from the copyright holder. To view a copy of this license, visit http://creativecommons.org/licenses/by/4.0/.

(c) The Author(s) 2020 